\title{
EDUCAÇÃO COMO CORPO-AFECÇÃO: LEITURA E CRIANÇAS EM FABULAÇÕES
}

\author{
Alberto d'Avila Coelho \\ Angelina Monica Monteiro dos Santos ${ }^{\mathrm{ii}}$
}

\begin{abstract}
Resumo: Este artigo parte de um projeto de pesquisa na área de Educação que problematizou momentos de leitura de uma professora com seus alunos, corpos a produzirem fabulações por afecções. Como um corpo físico funciona quando na escuta de obras literárias? Quais efeitos se podem notar nestes corpos? E como a Educação pode ser tratada como um corpo em movimento? Assim problematiza práticas de aula tendo o conceito de "corpo" como afecção, que se deseja em devir, desviando-se de uma forma identitária, fixa a um modelo. Encontrouse uma educação como corpo constituído na dissipação de forças pelas experimentações de uma professora consigo mesma, com o grupo de alunos e, também, com todos os elementos em agenciamento no espaço-tempo em que transcorreram as leituras.
\end{abstract}

Palavras-chave: Educação; Corpo; Leitura-corpo; Fabulação; Aula.

\section{EDUCATION AS BODY-AFFECTION READING AND CHILDREN IN FABULATIONS}

\begin{abstract}
This article starts off from a research project on the field of Education that discussed moments of a teacher reading with students, bodies producing fabulation from affections. How does a physical body react when listening to literary pieces? What are the effects that may be noticed in theses bodies? Furthermore, how may Education be treated as a body in movement? Therefore, it discusses class practices facing the concept of a "body" as affection that is desired in coming to be, deviating from an identitarian form fixed in model. We found an education as a body made up in the dissipation of forces by a teacher's own experiments with a group of students as well as with all the elements present within the timespace in which the readings take place.
\end{abstract}

Key-words: Education; Body; Reading-body; Fabulation; Class.

\section{Introdução}

Este artigo busca por um pensamento que constitua a Educação, em suas diferentes dimensões de atuação e compromissos, enquanto corpo cuja existência se dá pelo puro movimento e, justo por isso, se queira em devir, pois o devir trata de encontrar a zona de vizinhança, de indiscernibilidade ou de indiferenciação (...) que atravessa as formas do vivido (PIMENTEL, 2010, p. 135), desviadas as formas identitárias, imitativas ou miméticas. A educação feito corpo que não se contenta em aprisionar-se a um determinado modelo, (c) (1) (2) Licença Creative Commons Atribuição Não Comercial-Compartilha Igual (CC BY-NC-4.0), que permite uso, distribuição e reprodução para fins não comercias, com a citação dos autores e da fonte original e sob a mesma licença. 
muito pelo contrário. Porque busca situar-se na mistura de corpos, por afecções, por fabulações, apostando que ainda é possível sonhar. Sim, a educação como um tempo-espaço, no qual, assim como intuem as ideias na memória, também se componha o não-pensado, se experimente o não-dito. Educação molecular que se faz corpo em criação. Corpo em criação que se movimenta num sentido de dispersão e de junção simultaneamente.

Para pensar uma educação/corpo em movimento, este artigo recorta parte de um projeto de pesquisa na área de Educação, que se propôs a problematizar as práticas de leitura de uma professora junto a crianças de 6 e 7 anos de idade, dos primeiros e segundos anos do Ensino Fundamental. Foi por aí, neste tempo-espaço de um aprender com a arte da literatura, que as crianças produziram afecções com obras lidas em sala de aula, vivências que ocorreram a partir do ano de 2014, registradas em fotografias e apontamentos diários, material que serviu para dar suporte ao estudo investigativo.

Propondo uma educação se processando em ato, em devir, em desejo, nos fundamentamos em Jorge Larrosa (2015) quando aborda a educação e a produção de saber pelo viés da experiência/sentido. O autor propõe que exploremos juntos outra possibilidade, digamos que mais existencial (sem ser existencialista) e mais estética (sem ser esteticista), a saber, pensar a educação a partir do par experiência/sentido (LARROSA, 2015, p.16). Compondo seu texto com considerações e pertinências ímpares, Larrosa deixa claro o que não quer fazer, por considerar que muito já foi feito, ou seja, não quer especificar problemas da educação sob o ponto de vista da relação ciência e técnica ou, da relação teoria e prática. Pois bem, implicados como o par experiência/sentido desenvolveu-se a problemática deste artigo: entender a educação como um corpo em movimento.

Mas a educação pode assumir uma forma corporal? Como isso é possível? Sendo corpo em movimento, estaria feito de qual matéria ou substância? Para alcançarmos possíveis resultados quanto a estas indagações, o material que documentou os momentos de leitura da professora junto às crianças permitiu levantar outras questões mais específicas, quais sejam: como as crianças entendidas como "corpos" se apropriam da leitura em aula? Com quais forças cada corpo interage e produz fabulações? Quais encontros podem ser destacados nestes momentos de aprendizagem? Pode-se afirmar que nesse ato de leitura a educação assume-se como corpo em movimento? Na dissertação que fundamentou este artigo foi articulada basicamente, dentre outros, a noção de corpo como mistura de corpos, corpo em uma perspectiva espinosiana (SILVA, 2015; DELEUZE, 2001), associada à de potência fabuladora (PIMENTEL, 2010). 


\section{Corpo, afecções e leitura-corpo}

Recorre-se às ideias de Espinosa, filósofo do século XVII que escreveu a "Ética" (SILVA, 2000), para tratar do conceito de corpo, uma ciência dos afetos; e em Deleuze, na obra "Espinosa filosofia prática" (2002). Referimo-nos, assim, aos modos como um indivíduo se constitui no mundo, como ele se faz corpo no mundo, estendendo esse conceito para pensar corpos não-humanos, corpos constituídos em sua potência.

Espinosa entendia que por meio do corpo é que possivelmente pudéssemos entender melhor a alma. Para fazer um estudo da alma como tentativa de se aprofundar nela era necessário saber do que um corpo é capaz. Nos aponta Deleuze (2002), a propósito de Espinosa, que este é um entendimento que vinha à contramão do pensamento filosófico, havido até então, quanto a se pensar o corpo, pois o corpo excede o que dele conhecemos tanto quanto a alma. Para conhecer essa última, precisaríamos investir no conhecimento do primeiro e assim, quem sabe, ir tecendo paralelos e produzindo conhecimento sobre a alma.

$\mathrm{Na}$ época de Espinosa, havia um pensamento corrente sobre corpo e alma como partes distintas de uma pessoa, distanciadas uma da outra, não atendendo aos mesmos interesses. Estudos dessa natureza foram realizados por René Descartes, filósofo contemporâneo de Espinosa. Descartes tem sua última obra "As paixões da alma" escrita em 1649, ano em que Espinosa completava 17 anos. Para o filósofo do cogito "Penso logo existo", ambos, corpo e alma, tinham vontade própria, assim sacrificavam-se um ao outro para a exercerem.

Contrariando Descartes, a tese teórica conhecida como Paralelismo de Espinosa, não só nega a casualidade entre corpo e alma, como não hierarquiza um sobre o outro. Ele não partilha do pensamento tradicional vigente à época em que, de uma ou outra maneira, inclusive chegando aos nossos dias, se fundava a moral como um empreendimento de dominação da paixão pela consciência: quando o corpo agia, a alma padecia, dizia-se e a alma não atuava sem que o corpo padecesse por sua vez (DELEUZE, 2002, p.24). Espinosa pensava segundo outra ética na qual a ação na alma seria necessariamente uma ação no corpo e vice-versa. Deleuze vê Espinosa como filósofo da vida, que buscava denunciar tudo o que entendia separar-nos dela, o que incluía os valores transcendentais de orientação contrária a ela que, de uma forma ou outra, estariam vinculados à ilusão de nossa consciência. Mas afinal, como Espinosa define um corpo? (DELEUZE, 2002, p.128). 
Um corpo qualquer para ele - segundo Deleuze (2002) - se define por duas situações simultâneas que seriam sua individualidade e sua potência. Com relação à primeira, temos que um corpo é composto de uma imensidão de partículas, qualquer que seja ele - grande ou pequeno. Não tendo sua individualidade definida por forma, ou função, mas por uma menor ou maior velocidade de suas partículas entre si. Bem como, com relação à segunda, no que diz respeito ao corpo, não o definimos pelas suas funções, formas, ou órgãos, mas pela sua potência. Potência esta, tanto para afetar, quanto para ser afetado. Assim, temos que é pela capacidade de afeto que definiremos os corpos - um homem, uma idosa, uma criança, mas não só também por seres não pertencentes ao grupo dos humanos, como um animal de uma espécie ou de outra, assim como animais de uma mesma espécie, ao exemplo de um boi de arado de coice e outro de dianteira, chamado também de boi de guia.

Para Deleuze (2002) é do entendimento de Espinosa que toda coisa é corpo, corpo e ideia simultaneamente. Enquanto o espírito seria um modo de pensamento por uma ideia, o corpo seria um modo de extensão. Portanto, teríamos o espírito como ideia do corpo ao qual corresponde. Não temos entendimento do que somos, pelo menos não imediatamente. O que temos é uma ideia do que acontece ao corpo. Ideias de afecções do nosso corpo, e é apenas por elas que conhecemos imediatamente as coisas do mundo. O corpo e a alma não são substância nem sujeito, mas modos, e modos de afetar e ser afetado. É preciso pensar na necessidade de haver uma relação da pessoa com ela mesma. Tem que haver o interesse de um sujeito se relacionar com ele mesmo, mas não só, também com outras pessoas, com outros corpos. Se um corpo outro qualquer compõe com o nosso corpo, nos alegramos, e ao contrário disso nos entristecemos. O mesmo ocorre com a alma, se uma ideia agrega algo ao que pensamos, nos alegramos, caso contrário, nos entristecemos. Veremos mais adiante como esta composição por afecções ocorre durante os encontros das crianças com a leitura em sala de aula.

Todo este referencial filosófico espinosiano apresenta o corpo humano como um grau de potência, em sua capacidade de afetar e de ser afetado é assim que um indivíduo existe, em sua capacidade de mudar, alterar, fazer pensar o outro e de sofrer os mesmos processos também. Forças de afecção preenchem tal potência, rompendo seu limite. Com relação a tais afecções há duas espécies: sendo uma designada ação, de origem interna (a ativa) e a outra paixão, de origem externa (a passiva). E essa última dividindo-se em duas: a paixão da tristeza e a paixão da alegria. 
A paixão triste ocorre quando de um encontro com outro corpo, o interesse se choca, se decompõe. A tristeza para Espinosa não é boa, nela não há nada de bom. Pode-se pensar, por exemplo, em um tropicão na calçada; uma comida que não nos fez bem; um encontro com determinada pessoa, frente a qual nos sentimos mal, ou ainda, para retomar o tema deste artigo, com relação às ideias de um livro que não afetam, que não causa estranhamento, interesse e/ou comoção. O autor entendia que as pessoas tristes não viviam, o que faziam era manter a aparência de vida, uma vez que pensavam apenas em evitar a morte. Essa preocupação era entendida, por ele, como um culto à morte. Mas sair destas paixões tristes é necessário para que não sejamos tragados pela depressão e a morte. Como?

Das duas espécies de afecções tem-se que é pelas ações de origem interna, ativadora, que um indivíduo pode entender e dominar suas paixões, superando as tristezas ou aumentando suas alegrias. A paixão alegre é boa, e se dá quando os interesses se encontram, se somam - se compõem. Somente as paixões alegres valem a pena, assim resta pensar como alcançar o máximo de paixões alegres pelas ações, ainda que seja necessário encontrar modos de superar as tristezas. Podemos ver isso quando bebemos uma água fresca no calor do dia, saboreamos uma comida quando se está com fome quando encontramos pessoas cujas presenças fazem sentir-nos bem; quando estamos em relação a uma obra artística, música, filme, pintura ou livro que nos disparam o desejo.

Por falar em livro, temos o texto, a palavra, a leitura. Veremos a seguir, por conta de trazermos alguns relatos da professora-leitora, as suas paixões mais interessantes referidas a experiências com o universo da leitura e dos livros, cujas ideias afetaram e provocaram fabulações criadoras em si e, por efeito, em seus alunos quando a leitura alcançou seus corpos e os fez produzir fabulações agitando as almas. Ocorrendo em um estado de devir, o ser que fabula está atravessado por forças sensíveis.

O ser que fabula foi afetado por algo, maior que ele mesmo, algo com o qual ele não pode responder com seus recursos habituais, algo que foge de seus movimentos ordinários. Pode-se dizer que o indivíduo se deparou com um problema que o levou a fabular. Ou que criou para ele um campo fértil à fabulação. (ZACHARIAS; ZEPPIM, 2018, p.4)

Uma criança em escuta de uma obra literária se constitui corpo que percebe entrando em um estado de devir pelos atravessamentos que a história lhe causa, na forma de narrar da professora, nas alterações dos olhares e trejeitos dos colegas, nas intensidades que os 
personagens imprimem à narrativa; escapando aos seus hábitos as crianças passam por experiências que não estão acostumadas.

Obras literárias podem se oferecer como matéria de indagação da vida, oferecer-se como um estado de devir. Jogando a favor da vida tem-se o sonho e a fantasia para dar uma nova forma a realidade, "corrigir" suas imperfeições. Se faltar algo ao mundo a fabulação poderá o recriar, é daí que surgem inúmeras figuras esquisitas, seres divertidos, maldosos, arrogantes, preenchendo, assim, o que "falta" para tornar o mundo melhor habitável.

Há muitas forças em jogo atuando e provocando sentidos quando se lê um texto. Forças que se atravessam e alcançam de modo diferente em cada pessoa, cada corpo sensível, às vezes até passam despercebidas e nem chegam a alcançá-lo. Para que seja disparado em um corpo esta movimentação fabulatória, há uma condição básica: só pode afetar outros corpos um corpo afetado, só sensibiliza um corpo que está sensível às forças do mundo. Portanto, para afetar e provocar fabulações em seus alunos a professora-leitora também se viu tomada por um devir, um desejo, uma paixão alegre em suas tantas leituras. Passamos a ouvir uma experiência que ocorreu com a professora-leitora e o poema "Bocó" de Manuel de Barros (2006), fato de extrema importância para encaminhar o trabalho na perspectiva conceitual de corpo como um grau de potência, sendo um dos estopins para a escrita da pesquisa de onde se extraiu os resultados apresentados neste artigo. Ou seja, a professora-leitora também foi um corpo afetado e que pode, assim, afetar as crianças estimulando fabulações. Na leitura deste poema se pode dizer de uma experiência potencializadora ocorrida com a professora-leitora.

Pode-se dizer que "Bocó" é de uma raridade, o que pressupõe um trabalho das afecções acontecendo. Pelo viés do aumento do grau de potência, a leitura foi como uma flecha atingindo seu peito, junto ao agito das lembranças de infância fizeram ressoar as muitas vozes que um dia gritaram Bocó para ela. Hoje é sabido que se ela tivesse em mãos o dicionário com o "Bocó" não ficaria tão perdida, se livrando de cada um daqueles xingamentos. O poema "Bocó" é uma forma de expressão que atende todos aqueles que já se sentiram um dia bocó, com relação ao outro ou pela força explícita da fala de outro. Trata-se de uma questão individual, revelado no moço que catava pedra no rio até às $14 \mathrm{~h}$, momento em que a velha paraguaia passou e desfechou dizendo a palavra bocó, como poetisa lindamente Manoel de Barros.

Esta experiência da professora-leitora pode ser uma questão individual, mas ela reverbera no imediato político tendo seu enunciado coletivo. Ela fala, dá voz, para todos aqueles que sentem suas histórias se agitarem no texto, no corpo-texto, alterarem os processos 
que constituem uma vida imanente. Por isso, então, Manoel de Barros com seu "Bocó" potencializa a professora-leitora com seus 32 dicionários. Provoca um deslocamento que faz inventar um modo de leitura com o corpo, potencializando-o, colocando-o em devir.

Junto a tudo isso, a este processo que fez reviver lembranças de infância, veio também uma bordoada no coração da professora-leitora de livros para crianças. Como um corpo afetado, a partir do dia em que encontrou o "Bocó" começou a refletir sobre sua prática de leitura em aula. Nos momentos que se seguiram aquele encontro com "Bocó", pode observar nascer um forte desejo: que seus alunos tivessem experiências com a leitura em um forte grau de potência, como flecha que atinge o peito e faz tudo se deslocar, coisa que até então a leitora de livros para crianças não havia se permitido experienciar. O aprender, o educar, tem destas coisas.

Após ter sido sacudida, então, com a leitura do poema "Bocó", foi aos poucos se permitindo, na verdade mais que isso, saiu do entorno da permissão, passando a desejar ser a professora-leitura num devir-leitor. Ela se estimou e riu de gostar do que se passava com ela. Isso veio a causar transformações no seu modo de ler em sala de aula, dando um movimento próprio a ler e escutar com seus alunos. Leitura-corpo. E mais que isso, pois se uniu a outro movimento, o de uma professora que por vezes é aluna e de uma aluna que por vezes é professora, provocando movimentos simbióticos na leitura-corpo, pensando nas misturas de corpos como experiência que oferece aos seus alunos, e por ter vivido isso na própria pele.

Das paixões alegres da professora-leitora, de suas vivências em aula, as lembranças de quando empunhava um livro de contos e ao oralizar a leitura para as crianças, sabia que elas não estavam apenas ouvindo, mas fazendo cada uma delas suas leituras particulares, entravam em suas fabulações. O que se passava naquele instante com cada um daqueles alunos? Ao terminar a leitura, cada um tinha articulado cenas, conflitos, digressões e tudo afetado pela mesma voz a respirar forte ou lento, era a professora-leitora com seus fôlegos, olhadas, entonações, gargalhadas e silêncios.

Logo ao término da leitura, ao serem solicitadas para contarem o que fora escutado e imaginado, as crianças, por meio de suas percepções e impressões, por suas palavras e corpos tensionados, contavam de suas afecções, de suas paixões alegres e também tristes, davam o testemunho do que haviam ouvido, visto, sentido, de forma que se podia perceber que em cada criança, em cada corpo-alma, uma leitura surgia daquilo que fora aparentemente apresentado de igual forma pela professora-leitora. Cada criança como um corpo afetado pelo corpo-livro, corpo-texto, fazia emanar forças vibrantes a desenhar o espaço do pensamento. 
Por sua vez, a professora-leitora que oralizava o texto do livro, também estava a fabular, a ouvir-se contando e a proceder outras leituras do que estava no livro-afecções visuais, sonoras, táteis. A cada cena, forças de desventuras, de tormentos, de encantamentos, de regozijos, enquanto ela lia, o que lia também envolvia as crianças, ela percebia isso quando levantava seus olhos em varredura, de um lado para outro da sala. Via as crianças em seus sorrisos ou semblantes fechados, trejeitos de corpos, expressões diversas, ritmos cardíacos (quando estavam bem perto). E havia muitas vozes. Em alguns momentos elas falavam, amavam falar. Mas a professora-leitora também podia escutar as crianças mesmo que caladas. De maneira silenciosa a professora-leitora podia ouvir as crianças sobre o escutado, o visto, os sentidos do livro que segurava em suas mãos. À medida que as crianças ouviam o texto, faziam suas leituras sobre essa escuta. Se era desconhecida essa leitura, ela se dava boa parte em silêncio. Se conhecida delas, se de alguma forma já a tinham lido, mas em havendo dado novo que as provocassem ou entendessem que suas leituras estavam defasadas, ou ainda falhas, por um ou outro motivo, a experimentavam para obterem outras leituras, outras experiências.

As crianças liam a professora-leitora em seus movimentos e posturas. Foi desta forma que ela própria percebeu não haver um único movimento no ato de ler, movimento linear que vai daquele que oraliza o texto até outros que estão a ouvir, mas sim, há movimentos onde ambos os atores se movimentam produzindo muitos percursos com o que a história lida oferece.

Foi de posse dessas experiências, operacionalizadas com os conceitos filosóficos, que a professora-leitora passou a chamar o ato de ler para as crianças de "leitura-corpo", agora o modo de ler punha o ato de escutar em mesma relevância e durante esta atenção encontrava-se um corpo perceptivo e sensível se fazendo nas processualidades dos encontros, em afecções produtoras de sentido, como se a história que estava sendo lida não estivesse acabada, aguardando então o momento de ressoar pelo ambiente como palavras ao vento, e assim, seguir como que afetando quem com elas encontrasse admiração e matéria inventiva fabulatória.

Essa prática de leitura-corpo em aula não ocorreu numa aparente bipolaridade professor e aluno, mas se alastrou tomando o ambiente, pois agora se percebia uma leitura que ocupava o espaço-tempo da sala, que ampliava a condição de corpo físico (corpo-forma) para um corpo em vibrações, em fabulações, em devir (corpo-força). Até outros movimentos, como uma abertura ou um fechamento de porta, sineta, lousa, as disposições das cadeiras e o 
arrastar delas, o barulho da rua (carro, grito, tiro, sirene e por aí vai), o sol, a chuva, evidenciavam uma mistura que se fazia por estes corpos, graus de afecção, intensidades. Uma criança sensibilizada dá forma de expressão àquilo que vê e ouve. O texto lido de um livro ganha um "corpo", pois este afeta ao emitir uma cor, uma sonoridade, um jeito de se colocar na sala de aula são novas sensibilidades invadindo o espaço-tempo no ritmo das vozes na troca e na experimentação.

\section{Práticas de leitura-corpo}

Para sentirmos os efeitos de uma leitura-corpo vamos ao caso de uma menina de um primeiro ano com o conto "A princesa e a ervilha" de Hans Christian Andersen (TATAR, 2004), em como ele provocou uma leitura particular por afecções. Foi assim: certo dia, ao terminar o conto em uma turma, uma aluna de seis anos queria falar sobre sua experiência, mas tudo o que ela conseguia dizer era "museu". Dizia várias vezes essa palavra, ora com entonação no "u" primeiro da palavra, ora no último, ou ainda, no "e" e em seguida pronunciava vogais outras prolongadas, sem sentido, como se tivesse formulando o pensamento. Por vezes parava e de mãos estendidas para frente, gesticulando, em movimento de estar ainda falando, permanecia em silêncio e quando cobrada pelos colegas retomava a palavra dizendo "museu" nas variadas entonações de suas vogais. Ela pulava para falar. Ela dizia com o corpo bem ali na frente. A menina em sua expressão era aguardada com atenção, mas como demorava seus colegas estavam ficando irritados - eles também queriam falar. Então foi feito um pedido a ela, que primeiro ouvisse os colegas, para depois tentar falar novamente. Foi dada a vez da fala para as outras crianças, aproveitando para perguntar se conheciam algum museu, uma vez que era o assunto que a menina queria desenvolver pensando que isso a ajudaria a pensar/falar. Depois de alguns minutos voltou-se a ela, que enfim conseguiu dizer que tinha ido ao museu e que a ervilha estava lá. Todos riram. Para esclarecer: no final da história "A princesa e a ervilha" o autor dá uma saída inusitada para a ervilha, dizendo que fora guardada no museu e deve estar lá até hoje. Foi isso que deixou a menina tão eufórica.

Este relato permite pensar que, na história lida para a turma parecia que só o museu estava lá, era como se a menina tivesse esquecido ou não ouvido o restante. Refletindo sobre isso se percebe que a presença do museu no conto fora uma afecção da menina, de maneira 
que foi ali, naquela parte da história, que ela resolveu se demorar fabulando. Observados os trejeitos da menina, sua vontade de falar, sua dificuldade em expressar, a repetição da mesma palavra, isso aponta para o fato de que ela se deliciou com a leitura e não que ela pouco tenha acompanhado a leitura ou não a tenha "entendido". Ela poderia não ter efetivamente acompanhado a leitura se esta parte do conto tivesse ocorrido logo no início da história, pois ela estaria ocupada em fabular e não poderia mesmo dar conta de todo o resto.

Digredindo sobre a leitura deste conto e a experiência da leitura-corpo da menina, ela poderia ter ouvido falar da princesa batendo no portão e imaginar uma porteira de tábua (talvez), um chão de terra clara (ou não), varrido (ou não) e lá a princesa, e assim, parar neste local observando (a porteira, o chão de terra, a princesa...) e se apercebesse insatisfeita com a cor da roupa da princesa que inicialmente imaginara. Poderia pensar em outra e ir mudando azul para azul-claro, verde para verde-claro, rosa para rosa-claro. Mais claros ou mais escuros, bem como, mais longo ou mais curto. Também, se seria vestido saia ou calça. Poderia imaginar, quem sabe, o cabelo da princesa: seu comprimento, cor, penteado, com coroa ou tiara e estas com pedrarias ou não. Ou seja, as ideias fabuladoras de uma criança em leitura se articulam como passe de mágica, com o sumir e o aparecer instantâneo de objetos. Assim, estando a criança satisfeita com a aparência da princesa, poderia pensar em dar movimento imaginando-a andando. Se este andar tivesse meio grotesco, para o que ela teria como adequado para uma princesa, iria elaborar passos diferentes até alcançar experimentações mais potentes e inventivas.

O conto lido pela professora-leitora e a criança com seu imaginário concorrem a um espaço numa linha de tempo de forma a se desmembrar em outras narrativas, no momento ou posteriormente, até virem a se encontrar e caminhar juntas de novo, como um rio, em um movimento confluente. Contos outros brotam do conto lido. Ouvir as crianças no pós-leitura de forma aberta com relação ao tempo, ao pensamento, acatando as ideias e pensando sobre o lido é um modo de se observar esta formação em fluxos.

Outras experiências semelhantes a esta da menina que se envolveu de maneira tão intensa com uma pequena passagem da história, o caso do museu, ocorreram em outras visitas a escolas. Destacamos uma delas, onde duas turmas participaramdos encontros de leitura, uma de primeiro ano e outra de segundo. Nela é possível visualizar os percursos que podem ser provocados e construídos, simultaneamente, por uma única história quando contada para um grupo de crianças, estas ouvem um pouco, se distraem, voltam a ouvir, se dispersam, criam um roteiro todo próprio, que dá outra existência e colorido ao conto original. Vamos à visita. 
Na turma de primeiro anose observou o processo imaginativo de reconstrução de história, também a partir do conto "A princesa e a ervilha" de Hans Christian Andersen (TATAR, 2004), realizado de forma bem individual - um processo um tanto solitário de cada criança, mas rico em aspectos imaginativos, apesar da leitura para estas crianças ter provocado um cansaço, pois era um conto de sete páginas de letras bem miúdas. Já na turma do segundo ano, com o conto dos irmãos Grimm "O Rei Sapo", na tradução de Tatiana Belinsky (GRIMM, 1989), a história coletiva de alguns alunos em aula extrapolou as expectativas.

Pode-se dizer que desde a entrada da professora-leitora na primeira sala desta escola, parecia que o dia não seria propício, quando já no começo do trabalho se confirmava as suspeitas sobre um dia cansativo, olhar aquelas carinhas amuadas dava vontade de atirar o livro longe e sumir dali. E ainda mais que era o começo das atividades da professora-leitora, ou seja, ainda lhe faltava certa prática, um melhor manejo quando se tem condicionado aqueles problemas que se tornarão comuns, mas que leva certo tempo. Porém, o que pareceria seguir na turma do segundo ano acabou sendo modificado surpreendentemente, apesar de haver o mesmo começo igual ao que passou na turma do primeiro ano. Com um pouco de cuidado e insistência o ambiente foi mudando, sinais de certa animação apareceram em meio aos alunos.

Lá pelas tantas da leitura do conto "O Rei Sapo", surgiu uma carruagem atrelada a seis cavalos brancos enfeitados com pluma na cabeça. Os olhinhos riram olhando uns para os outros. Veio em seguida a frase "O fiel Henrique cocheiro do rei... aquele que conduzia a carruagem do rei...". Dois alunos apontaram para o aluno que se chamava Henrique. Riram. O sorriso da professora-leitora neste momento com uma paradinha (extra) na leitura proporcionou ambiente receptivo para que ele levantasse suas duas mãos alcançando as rédeas do cavalo que conduzia a carruagem, personificando o Henrique - fiel cocheiro do Rei. Com a mão chamou o irmão, que estava do lado, para mais perto e ambos de costa ereta conduziam a carruagem enquanto a história do livro seguia — juntos. Três alunos outros levantaram (em silêncio) e se puseram atrás da carteira deles. Eram os conduzidos. Logo um deles ficou com vergonha (ficou com as bochechas vermelhas) e voltou para o lugar, os outros dois seguiram a viagem. Com acenos ligeiros, assobios sem som (para não fazer barulho) foram dando volume a esta cena imaginária, produziram outra história dentro da que era contada, na qual participavam ativamente. 
Esta leitura-corpo do conto, de maneira individual, movimentou as crianças do primeiro ano e também as do segundo, o qual as crianças além de apresentar uma produção individual, cada uma delas, se empenharam na fabulação e conexões enquanto grupo. Assim, entraram na obra de corpo e alma, com vontade, em leitura passearam nela fazendo percursos únicos. Procederam por sobressaltos do real-ficção ao real-imaginação e vice-versa. Encontraram-se no desejo de explorar cada pedacinho da leitura que sobressai aos seus olhos. E fizeram de forma livre, imaginativa, criativa, atemporal e quando surgiu a oportunidade compartilharam aquele momento mágico. Pararam em determinados pontos, apreciaram suas possibilidades para além do que é dado, para além do que é delimitado pelas palavras, para além da hermenêutica, já no campo do indizível — O museu daquela aluna era um indizível.

\section{Das articulações à visão do corpo em desejo e criação - algumas considerações}

Após passar por estes momentos de leitura da professora com suas crianças, nos encaminhamos para o final deste artigo ponderando: quando se flexibiliza a leitura em atenção a um corpo que se produz por paixões, sejam alegres ou tristes, e por ações, na medida em que empenha articulações com aquilo que a história conta é possível neste instante ver o corpo em desejo e criação.

Na composição de cada cena de leitura-corpo tivemos corpos infantis alterados em seu grau de potência. Isso permitiu ver como um indivíduo promove sua existência ao experimentar sua capacidade fabuladora e romper os limites do real, por sua capacidade de afetar e de ser afetado.

Para que processos imaginativos sejam disparados com as histórias contadas precisa-se um tanto de liberdade, a criança no momento da leitura precisa sentir-se livre para se mover em sua cadeira, aos olhos do professor para observar um mosquito passando se quiser. Quando se vivencia em aula um movimento contínuo, simbiótico de escuta, um envolvimento por afecções que se dá entre crianças e professor-leitor é possível ser percebida uma leituracorpo que não para no ato de o professor ler uma obra literária, mas tem sua continuidade quando do retorno da leitura que as crianças procederam do texto lido. E a adição de um ponto que não existe na história lida, uma pequena pausa, a retomada do parágrafo de um lugar em que retome o sentido, pode facilitar imediatamente o surgimento de um conto coletivo em aula. Um processo de leitura-corpo dispara possibilidades que fluem com a 
criança, corpo em processos de imaginação, de criação, de fabulação. E também flui quando a professora-leitora altera a si mesma, não apenas ao selecionar as obras, mas quando passa a olhá-las como potência de vida capaz de produzir leituras que dão matéria à fabulação, experiência realizada no próprio corpo. Entra-se na obra literária não pelo limite aparente da palavra, das frases e parágrafos, mas em sede, em desejo de explorar. Não apenas no que diz respeito à linguagem, mas também por aquilo que é indizível — forças e afecções.

A potência fabuladora da criança, em um exercício também de produção, quando não exposta a impedimentos, consegue cavar seu próprio conto no conto dado. Ouvir um conto é se expor a paixões, sejam alegres ou tristes. Quando uma tristeza vai se aproximando, bem devagar, pressentimos que aguardar o desenrolar da história será uma saída e isso é bem comum de acontecer. Sabemos, por Espinosa, que viver na tristeza não queremos, a tristeza é só uma aparência de vida. E um livro nos reserva surpresas podendo até mesmo fazer com o que era triste se transformarcom as forças das paixões alegres. No fundo sabemos que no final ouviremos aquele "e foram felizes para sempre", ainda que descordando dos desfechos.

Podemos ver que pelo viés da leitura-corpo, a professora-leitora trouxe para suas crianças obras que potencializassem os encontros, inclusive com reverberações políticas e enunciados coletivos. Ainda que estas características pareçam ressoar um tanto fortes para serem encontradas em experiências com livros infantis é importante destacar que se trata de um trabalho de construção, de formação, de acompanhamento de futuros seres coletivos, portanto, desde esta tenra idade é fundamental que eles já sejam submetidos a experimentações com leitura-corpo de livros cujo teor, mesmo atrelado ao mundo infantil, possua força ética e política que pode, de alguma forma, orientá-los e acompanhá-los em suas vidas sem abrir mão da potência de fabulação. A política aqui sendo entendida como relações que forçam a produzir um pensamento quando se chocam saberes dispares.

Valendo-se das experiências da professora, quando esta faz coisas com as palavras lidas para as crianças, fomos acompanhando como ela deu sentido ao que era com o que acontecia consigo, com as crianças, com a literatura, com a sala de aula, enfim, com o que configura um modo de fazer e dar corpo a uma Educação em prática, em ato. Por aí, com uma atenção voltada as atuações desta professora-leitora com as crianças (formação docente, estética, ética) e do que ressoou como educação. O argumento principal deste artigo trouxe a ideia de corpo em movimento quanto ao que as aulas davam a ver, nos afetos desprendidos em cada cena, ao mostrar a professora-leitora lendo ou se fazendo ler/escutar, ou seja, um modo de perceber e aprender que toma o corpo físico em uma ação atenta e vai se mostrando, 
se desenhando em criativas fabulações, até alcançar um "corpo-força" (COELHO, 2015, p.12), absorvendo o corpo-forma. Foi justamente por pensar o ato de ler em sala de aula, e dos sujeitos envolvidos no processo, que se marcou um ponto na onda, lá onde as coisas fluem e o sentido, ou muitos sentidos, tornam-se referência para a produção de um pensamento.

Retomemos a questão: a educação pode assumir uma forma corporal? Positivamos a questão e damos um "sim" quanto a afirmar que em momentos de leitura a educação assumese corpo em movimento. Há muitos modos de se entender educação, pensar educação, tratar educação, mas quanto a apontá-la enquanto corpo em movimento, julgando não se tratar de um corpo humano ou animal, abrir-se a outras áreas do saber aumenta as possibilidades de se argumentar. Para tratarmos desta questão nos valemos da literatura e da filosofia como campos de saberes que ofereceram suporte teórico e experimentações que foram ao encontro das nossas considerações quanto a educação pode ser corpo ou constituir-se corpo.

Quando a educação se faz de uma matéria viva, não vista a olho nu, mas percebida nos corpos que fazem educação em ato, ela é corpo de intensidades. Esta ideia de educação a coloca em devir, se compondo na dissipação de forças. Quando capturados por esta possibilidade nos deparamos com um pensamento que envolve educação e corpo, no tempoespaço dos encontros em sala de aula e no desejo de fabulação e invenção, resulta o que este artigo se propôs, ou seja, tratar de Educação como corpo em movimento intensivo, em deslocamento, um corpo que vibra, que é vibrátil, que se efetua nos corpos que atuam na educação. Pela literatura e filosofia propomos fabular uma educação que busca alterar seus estados de letargia e fixação de modelos, estendendo-se as forças que vibram e que permitem outros modos de fazer com que um aprendizado ocorra. Fazer-se professor em afecção com seus alunos, apostar em processos fabuladores, foi a nossa tentativa.

\section{REFERÊECIAS}

ALMEIDA, F. L. Gato que pulava em sapato. 19ª ed. São Paulo: Ática, 2008.

ANDERSEN, H. C. A princesa e a ervilha. In:TATAR, M. (org.). Contos de fadas: edição comentada e ilustrada. (Trad. de Maria Luiza X. de A. Borges). Rio de Janeiro: Jorge Zahar, 2004.

O patinho feio. In: PERRAULT C. et al. (orgs.) Contos de fadas de Perrault, Grimm, Andersen \& outros. Apresentação: Ana Maria machado. (Trad. de Maria Luiza X. de A. Borges). Rio de Janeiro: Jorge Zahar, 2010. 
BARROS, M. Memórias inventadas: a segunda infância. São Paulo: Editora Planeta do Brasil, 2006.

CARPEAUX, O. M. A história concisa da literatura alemã. São Paulo: Faro Editorial, 2013. Disponível em: <https://www.passeidireto.com/arquivo/5489407/a-historia-concisa-daliteratura-alema--otto-maria-carpeaux> Acesso em: 08/10/2016.

COELHO, Alberto. Produção de sentido: imagem, arte e mistura de corpos(2015). Disponível em: https://seer.ufrgs.br/gearte/article/viewFile/53714/34863. Acesso em: 12 jun 2019.

DELEUZE, G. Crítica e clínica. (Trad. de Peter PálPelbart). São Paulo: Editora 34, 1997. . Espinosa filosofia prática. (Trad. de Daniel Lins e Fabien Pascal Lins). São Paulo, Escuta, 2002.

DELEUZE, G; GUATTARI, F. Kafka: por uma literatura menor. (Trad. de Júlio Castañon Guimarães). Rio de Janeiro: Imago,1977.

ERLBRUCH, W. O pato a morte e a tulipa. (Trad. de José Carlos Macedo; ilustração de Wolf Erlbruch). São Paulo: Cosac Naify, 2009.

GRIMM.João e Maria.In: PERRAULT (et al.). Contos de fadas de Perrault, Grimm, Andersen \& outros. (Trad. de Maria Luiza X. de A. Borges). Rio de Janeiro: Jorge Zahar, 2010.

GRIMM. O Rei sapo. In: Os contos de Grimm. (Trad. de Tatiana Belinsky, ilustração de JanszGrubianski), 4ª ed. São Paulo: Editora Paulus, 1989.

MARINHO, Jorge Miguel. Fabulação: um mundo onde todos sonham(2015).

Disponível em: http://www.plataformadoletramento.org.br/em-revista/384/fabular-epreciso.html. Acesso: 03 mai. 2019.

MEIRELLES, C. Ou isto ou aquilo. Rio de Janeiro: Nova Fronteira, 1990. Disponível em: <http://zezepina.utopia.com.br/poesia/poesia128.html> Acesso em: 14 nov. 2017.

PIMENTEL, Mariana Rodrigues; SCHOLLHAMMER, Karl Erik. Fabulação:a memória do futuro. Rio de Janeiro, 2010. 152p. Tese de Doutorado - Departamento de Letras, Pontifícia Universidade Católica do Rio de Janeiro.

ROLNIK, Suely. Uma insólita viagem à subjetividade fronteiras com a ética e a cultura. Disponível em: http://www.caosmose.net/suelyrolnik/pdf/sujeticabourdieu.pdf. Acesso em: 12 jun. 2019.

ROLNIK, Suely. "Fale com ele" ou como tratar o corpo vibrátil em coma (2003). Disponível em:

https://www.pucsp.br/nucleodesubjetividade/Textos/SUELY/falecomele.pdf?fbclid=IwAR1b D8C79KW2TH6N7_vXGCbYHGaGrbc9rTDplpozNHFCeIznFwKzFzq0Vks. Acesso em: 04 mai. 2019. 
SILVA, Tomaz Tadeu da. Ética. Belo Horizonte: Autêntica, 2007.

ZACHARIAS, Pamela; ZEPPIM, Paola S. Sobre aprender e fabular em educação (2018). Disponível em: http://lm.alb.org.br/index.php/lm/article/view/56. Acesso: 24 mai. 2019.

${ }^{i}$ Professor efetivo, titular, doutor em Artes Visuais, atua no Departamento de Graduação e Pós-graduação, do Instituto Federal Sul-rio-grandense (IFSUL), campus Pelotas/ RS, Brasil. E-mail: alberto@ pelotas.ifsul.edu.br. ORCID http://orcid.org/0000-0001-7700-9108.

${ }^{i i}$ Mestre em Educação pelo Instituto Federal Sul-rio-grandense (IFSUL). Graduada em Pedagogia pela Universidade Federal de Pelotas/ RS, Brasil. E-mail: angelinamonteiro3@gmail.com

ORCID http://orcid.org/0000-0001-7978-6912. 